\title{
Prevalence of latent virus in Spodoptera litura (Fabricius) (Lepidoptera: Noctuidae) and its activation by a heterologous virus
}

\author{
Lucien N'Guessan Kouassi, ${ }^{1}$ Katsuo Tsuda, ${ }^{1, *}$ Chie Goto, ${ }^{2}$ Shigeyuki Mukawa, ${ }^{2}$ \\ Yositaka SAKAMAKI, ${ }^{1}$ Kanetosi KuSIGEMATI $^{1}$ and Masayuki NAKAMURA ${ }^{1}$ \\ ${ }^{1}$ Laboratory of Plant Pathology and Entomology, Faculty of Agriculture, Kagoshima University; Kagoshima 890-0065, Japan \\ ${ }^{2}$ Insect Pest Management Research Team, National Agricultural Research Center; Tsukuba, Ibaraki 305-8666, Japan
}

(Received 26 June 2008; Accepted 24 September 2008)

\begin{abstract}
Nested PCR amplification of a Spodoptera litura nucleopolyhedrovirus (SpltNPV) lef-8 gene fragment was performed on egg masses and larvae of $S$. litura, and resulted in detection of a latent SpltNPV in $20.0 \%$ of "healthy" laboratory stock samples, and in $22.6 \%$ of samples collected at different periods and in remote places in Kagoshima Prefecture. The PCR product sequences showed $99 \%$ similarity to the published lef- 8 sequence of SpltNPV, confirming that the amplification products were derived from SpltNPV. Further, cross-inoculation of laboratory stock S. litura larvae with Mythimna separata NPV (MyseNPV) activated the latent virus, which provoked a change in the virulence of MyseNPV samples collected from cadavers of $S$. litura. Our data suggest that caution should be taken when using $S$. litura as a host to produce heterologous NPVs.
\end{abstract}

Key words: Spodoptera litura; latent virus; activation; nested PCR; virulence variation

\section{INTRODUCTION}

Due to their pronounced host specificity and high virulence to susceptible insect hosts, nucleopolyhedroviruses (NPVs) of the Baculoviridae are being developed as biocontrol agents for lepidopteran pest insects. Before application as biopesticides, however, a range of experimental studies including identification, host range determination, and efficacy evaluation are necessary. Currently, the cheapest way to produce NPVs for such studies is by propagation through host insects, and although this is usually accomplished in the homologous host species there are occasional exceptions. For example, in Japan, the production of viruses for experimental use has been carried out in Spodoptera litura (Fabricius) (Lepidoptera: Noctuidae) larvae because this insect is permissive to some viruses (Okada, 1977; Tsuda et al., 2005), is easy to rear, and is large enough to yield substantial amounts of virus for assays. However, the production of viruses in a heterologous host entails the risk that activation of a latent virus might lead to a false interpretation of bioassay results. Latency describes the state of a virus that does not produce obvious signs of infection, including sublethal effects, but can be vertically transmitted between host generations (Hale and Margham, 1988). Concerning insects, latent virus has intrigued researchers for many years, but only with recent molecular techniques has it become possible to demonstrate with accuracy the presence of insect latent virus and understand its mechanism (reviewed by Podgwaite and Mazzone, 1986; Il'inykh and Ul'yanova, 2005).

Triggers or stress factors such as extreme temperatures, crowding, high humidity, and unsuitable diet can convert a latent to an overt infection (Fuxa et al., 1999). Although true cross-infection may occur during a cross-inoculation (El-Salamouny et al., 2003; Jakubowska et al., 2005), numerous reports have also shown that cross-inoculation testing with heterologous baculovirus isolates is the best stressor for production of a different virus progeny (i.e., the host's own virus) (Longworth and Cunningham, 1968; Maleki-Milani, 1978; Jurkovíčová,

* To whom correspondence should be addressed at: E-mail: ktsuda@agri.kagoshima-u.ac.jp DOI: 10.1303/aez.2009.95 
1979; McKinley et al., 1981; Cory et al., 2000). While latent viruses have been studied in several insects, nothing is known about their occurrence in $S$. litura, although it is an important pest species in Japan.

In this study, we address two issues: the first is to determine whether S. litura harbors latent NPV, and to evaluate the prevalence of latent infection in field insects and laboratory stock. The second is to assess the effects of latent virus when heterologous NPVs are propagated in laboratory stock of $S$. litura.

\section{MATERIALS AND METHODS}

Insects. Two types of insects were used in this study. The first type consisted of laboratory stocks of S. litura and Mythimna separata (Walker) (Lepidoptera: Noctuidae) that were collected from fields in Kagoshima Prefecture in 1997 and 2003, respectively. Both species were reared continuously in the laboratory at ca. $25^{\circ} \mathrm{C}$ on artificial diet (Okada, 1977), prepared by a modified process in which dried maize leaves and soybean were used instead of dried pinto beans.

The second type were larvae and egg masses of $S$. litura collected in September, November, and December 2007 from fields in three geographical locations of Kagoshima Prefecture (Kagoshima City, Ibusuki City, Kanoya City). Egg masses, or larvae from the same egg mass, were divided into two batches: one was reared until the next generation according to the procedure described above, and the other was stored at $-20^{\circ} \mathrm{C}$ for DNA extraction. This type represented our field-collected insects.

Viruses. The M. separata NPV Geihoku isolate (MyseNPV G) was discovered in Geihoku, Hiroshima Prefecture, in 1968 (Okada, 1977). MyseNPV G was propagated in larvae of M. separata, and the collected virus was then propagated through $S$. litura. The viruses collected from cadavers of M. separata and $S$. litura were named MyseNPV G (M) and MyseNPV G (S), respectively. Occlusion bodies (OBs) of these two types of viruses were purified by glycerol density gradient centrifugation (Hunter-Fujita et al., 1998), and then suspended in distilled water. OBs in the suspension were counted with a Thoma hemocytometer and stored at $4^{\circ} \mathrm{C}$ until use.
Extraction of DNA from insects, nested PCR amplification, and sequencing. To avoid contamination by exogenous virus or DNA, all plasticware used in this study (microtubes, homogenizers, tips, petri dishes) was disposable and sterilized before the experiments.

One egg mass or larvae from the same egg mass were considered as one sample. Laboratory stock and field-collected $S$. litura samples were ground in DNA extraction buffer $(0.15 \mathrm{M} \mathrm{NaCl}, 50 \mathrm{~mm}$ Tris$\mathrm{HCl}, 10 \mathrm{~mm}$ EDTA, 1\% SDS, pH 8.0), incubated at $65^{\circ} \mathrm{C}$ for $20 \mathrm{~min}$, and centrifuged at $16,000 \times g$ for $10 \mathrm{~min}$. DNA in the supernatant was extracted by phenol-chloroform, collected by ethanol precipitation, suspended in TE buffer $(10 \mathrm{~mm}$ Tris- $\mathrm{HCl}$, 1 mM EDTA, pH 8.0), and stored at $4^{\circ} \mathrm{C}$. The DNA was then used in a nested PCR reaction.

First, about $500 \mathrm{ng}$ of DNA was used to amplify a 241-bp fragment of the late expression factor- 8 (lef-8) gene of S. litura NPV (SpltNPV) (GenBank Accession No. AY706581) using the primers SINPVlef-8F3 (5'-CGACGTTTTCGTGCAAAC-3') and SINPVlef-8R3 (5'-GTCGACGATCCGAGCTTT-3'), whose specificity was maximized by selecting a region which showed low sequence similarity with MyseNPV G (AB308407). The PCR amplification was performed in a reaction mixture of $10 \mu \mathrm{l}$ using the following conditions: initial denaturation of $3 \mathrm{~min}$ at $94^{\circ} \mathrm{C} ; 30$ cycles of $20 \mathrm{~s}$ at $94^{\circ} \mathrm{C}$, $20 \mathrm{~s}$ at $60^{\circ} \mathrm{C}, 45 \mathrm{~s}$ at $72^{\circ} \mathrm{C}$; and final extension of $5 \mathrm{~min}$ at $72^{\circ} \mathrm{C}$. The PCR products $(8 \mu \mathrm{l})$ were separated in a $1 \%$ agarose gel along with a $100 \mathrm{bp}$ ladder (Takara Bio, Japan), and the remaining $2 \mu 1$ was added to a PCR mixture to amplify a nested 217-bp product of the same gene, using the conditions described above and the low-similarity-region primers SINPVlef-8Fnes (5'-ACGAAAGCATCTAGTGCG-3') and SINPVlef-8Rnes (5'-CCGAGCTTTGATTTGAGC-3'). The PCR products were then separated in an agarose gel as described above.

For DNA sequencing, fragments amplified by nested PCR were ligated into pT7Blue T-Vector (Novagen, Germany) and cloned in Epicurian coli XL1-Blue (Stratagene, USA). Sequencing was carried out with a Big Dye ${ }^{\mathrm{TM}}$ terminator Cycle Sequencing Ready Reaction Kit (Applied Biosystems, USA) using T7 and M13 M4 primers on an ABI Prism 3100 Genetic Analyzer apparatus (Applied Biosystems). Analysis of sequencing data 
was carried out using GENETYX-MAC Network version 13.0.3 (GENETYX Corp., Japan).

Viral DNA extraction and analysis. The purified OBs isolated from dead larvae were incubated in $0.02 \mathrm{M} \mathrm{NaOH}$ for $10 \mathrm{~min}$ to release virions, and centrifuged at $13,000 \times g$ for $30 \mathrm{~min}$. Virions were disrupted by suspending the pellet in TE buffer containing $1 \%$ SDS and $200 \mu \mathrm{g} / \mathrm{ml}$ proteinase $\mathrm{K}$, and incubating the mixture at $55^{\circ} \mathrm{C}$ for $3 \mathrm{~h}$. DNA was extracted as described above, and either digested with EcoRI (Takara Bio) for $4 \mathrm{~h}$ or used in a PCR reaction with the SINPVlef-8F3/SINPVlef8 R3 primer pair as described above. For the other reaction, amplification of the partial lef- 8 gene was performed according to the method of Lange et al. (2004), using degenerate primer pairs (prL8-1B, prL8-2; Jehle et al., 2006), with minor modifications. Amplification reactions were performed under touchdown PCR cycling conditions: step 1: $94^{\circ} \mathrm{C}$ denaturing for $3 \mathrm{~min}$; step $2: 94^{\circ} \mathrm{C}$ for $20 \mathrm{~s}$, $55^{\circ} \mathrm{C}$ for $20 \mathrm{~s}$ (ramping $3^{\circ} \mathrm{C}$ per 3 cycles), $72^{\circ} \mathrm{C}$ for $45 \mathrm{~s}$ (step 2 cycled 15 times); step 3: a further 20 cycles as above but without ramping, at a fixed annealing temperature of $60^{\circ} \mathrm{C}$, followed by a final elongation step of $72^{\circ} \mathrm{C}$ for $5 \mathrm{~min}$. PCR products were then sequenced and analyzed as described above.

Bioassays. Bioassays were conducted in two ways. In the first, third-instar S. litura and M. separata were challenged with both MyseNPV G (M) and MyseNPV G (S). Virus preparations were serially diluted from $10^{9}$ to $10^{2} \mathrm{OBs} / \mathrm{ml}$, and $10-\mu 1$ aliquots of four to eight virus concentrations were spread on small pieces of artificial diet in glass test tubes. Twenty-five newly molted larvae were allowed to feed individually on the contaminated diet for $48 \mathrm{~h}$, and then transferred to virus-free diet. As controls, larvae were fed on artificial diet without virus suspension. All treatments were incubated at $25^{\circ} \mathrm{C}$ in a 14-h light and 10 -h dark photoperiod. Mortality due to infection was monitored daily until death or pupation. Bioassays with MyseNPV $\mathrm{G}(\mathrm{M})$ were replicated three times in both species, and those with MyseNPV G (S) were replicated 4 times and twice in $M$. separata and $S$. litura, respectively. The median lethal concentration $\left(\mathrm{LC}_{50}\right)$ with the respective 95\% confidence limits (CLs) was estimated for both viruses in both species by probit analyses (Finney, 1978) using the program PriProbit 1.63 (Sakuma, 1998). The ratio of $\mathrm{LC}_{50} \mathrm{~s}$ between the two hosts for MyseNPV G (M) and MyseNPV G (S) was calculated by the method of Robertson and Preisler (1992).

In the second bioassay method, MyseNPV G (M) was used to infect 115 third-instar larvae of $S$. litura. Dead larvae were homogenized individually with $500 \mu \mathrm{l}$ of distilled water. Each homogenate was inoculated into 5 third-instar $M$. separata and/or S. litura larvae. Mortality was recorded, and the presence of OBs in tissue smears of dead larvae was confirmed by phase contrast microscopy at $\times 400$ magnification.

\section{RESULTS}

\section{PCR amplification and sequencing of SpltNPV lef-8 gene fragment from $S$. litura}

PCR amplification of the SpltNPV lef- 8 gene fragment was performed on egg masses and larvae of $S$. litura to detect SpltNPV in "healthy" S. litura. Although no product was visible in the first PCR reaction, nested PCR of several samples yielded a 217-bp fragment (Fig. 1). The PCR product was detected in egg masses and larvae of insects from laboratory stock. It was also found in field-collected samples, at all places and periods of collection (Table 1). The product was detected in $20.0 \%$ and $22.6 \%$ of laboratory stock and field-collected samples, respectively. All offspring derived from the insect batches not used for DNA extraction survived without any apparent symptoms of viral infection.

To make certain that the PCR product was not generated by $S$. litura DNA but by SpltNPV, se-

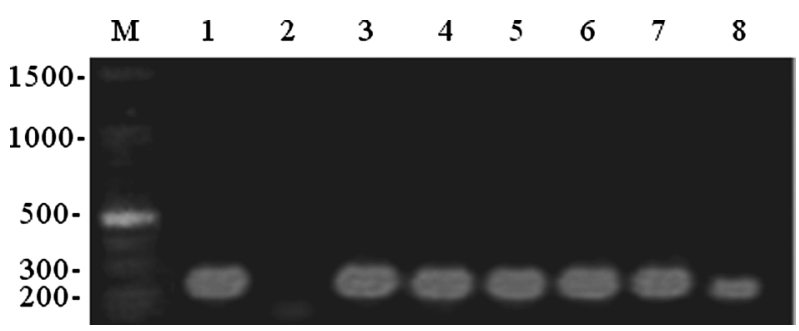

Fig. 1. Detection of SpltNPV lef-8 217-bp fragment by nested PCR. Lanes 1 and 2, larvae and eggs of laboratory stock S. litura, respectively; lanes 3 and 4, larvae and eggs of Kagoshima field-collected $S$. litura, respectively; lanes 5 and 6 , larvae and eggs of Ibusuki field-collected $S$. litura, respectively; lane 7, larvae of Kanoya field-collected $S$. litura; lane 8, PCR positive control (SpltNPV DNA); lane M, 100 bp ladder size marker. 
quencing of the lef- 8 nested PCR product of one sample each from laboratory stock (GenBank Accession No. AB451186) and field-collected insects (from Kanoya City) (GenBank Accession No. AB451185) was performed. BLAST searching showed $99 \%$ and $90 \%$ similarity with the published

Table 1. Detection by nested PCR of S. litura latent virus in S. litura collected at different periods and in separate localities in Kagoshima Prefecture

\begin{tabular}{lcccl}
\hline \multirow{2}{*}{$\begin{array}{c}\text { Period } \\
\text { (2007) }\end{array}$} & \multicolumn{3}{c}{ Geographic location } & \\
\cline { 2 - 4 } & Kagoshima & Ibusuki & Kanoya & \\
\hline September & $8 / 21$ & $2 / 13$ & $3 / 9$ & $13 / 43$ \\
November & $5 / 9$ & $6 / 37$ & $1 / 56$ & $12 / 102$ \\
December & $2 / 5$ & $2 / 10$ & $14 / 30$ & $18 / 42$ \\
Total & $15 / 35$ & $10 / 60$ & $18 / 95$ & $43 / 190$ \\
\hline
\end{tabular}

$x / y$ : number of samples (larvae and eggs) in which SpltNPV gene was detected/number tested. lef-8 sequences of SpltNPV (AY706581) and SpliNPV (AY706585), respectively, confirming that the amplification product was derived from SpltNPV (Fig. 2).

To ascertain whether any naturally occurring SpltNPV on the surface of field insects might interfere with our results, five samples that proved negative for SpltNPV by nested PCR were mixed with DNA extraction buffer containing $10^{2}$ OBs of SpltNPV. DNA extraction and PCR amplification were carried out as usual. No viral DNA was detected, proving that any virus present on the surface of insect material was not amplified and hence did not interfere with detection assays (data not shown).

\section{Pathogenicity of MyseNPV types}

Table 2 shows the relative pathogenicity of MyseNPV G (M) and MyseNPV G (S) against thirdinstar larvae of $M$. separata and $S$. litura. According to the $95 \% \mathrm{CLs}$ of the $\mathrm{LC}_{50}$ values, while $M$.

\begin{tabular}{|c|c|}
\hline Field & CGAAAGCATCTAGTGCGCATCGTGTACGAGTTTAAACGCAAACGG TTTCCCGTCGAGATC \\
\hline Laboratory & CGAДAGCATCTAGTGCGCATCGTGTACGAGTTTAдACGCAДACGGTTTCCCGTCGAGATC \\
\hline SpltNPV & СGAAAGCATCTAGTGCGCATCGTGTACGAGTTTAAACGCAAACGGTTTCCCGTCGAGATC \\
\hline SpliNPV & СGAДAGCATCTAGTACGCATCGTGTACGAGTTTAAACGCAAACGGTTTCCAGTCGAGATC \\
\hline Field & ААДCTGTTTAAДGATATTCTATTTGTCAATCATCACGAAGGCATGATATGTATACGCAАA \\
\hline Laboratory & 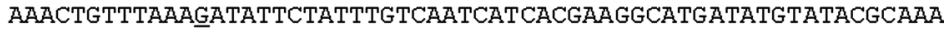 \\
\hline SpltNPV & 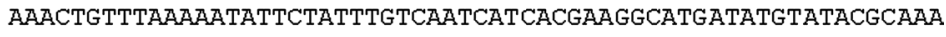 \\
\hline SpliNPV & 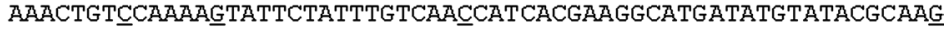 \\
\hline Field & 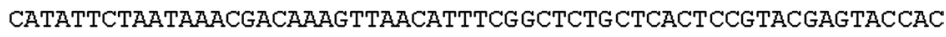 \\
\hline Laboratory & 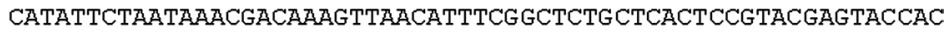 \\
\hline SpltNPV & 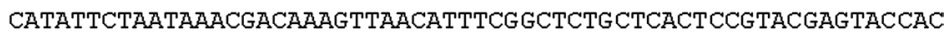 \\
\hline SpliNPV & CAGGTTCGAдTAДATGAдАДAGTДдАCATTTCGGCGCTGCTCACTCCGTACGAGTACCAC \\
\hline Field & AАCGGCGAДTСTATTGTTGCTCДAДTCAДAGCTCGGA \\
\hline Laboratory & 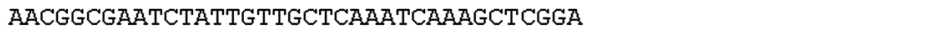 \\
\hline SpltNPV & 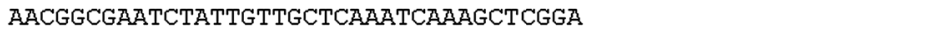 \\
\hline SpliNPV & 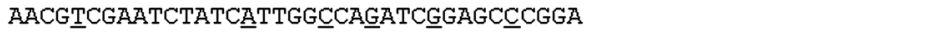 \\
\hline
\end{tabular}

Fig. 2. Alignment of amplified SpltNPV lef-8 217-bp sequence from DNA extracted from laboratory stock (Laboratory) and field-collected (Field) $S$. litura with the partial nucleotide sequences of $S$. litura NPV (SpltNPV) and S. littoralis NPV (SpliNPV) in GenBank. Underlined letters indicate nucleotides which differ from the SpltNPV sequence.

Table 2. Dose mortality response of third instar larvae of Spodoptera litura and Mythimna separata following inoculation with MyseNPV G (M) and MyseNPV G (S)

\begin{tabular}{clccccc}
\hline Virus & \multicolumn{1}{c}{ Host } & $\mathrm{LC}_{50}(95 \% \mathrm{CL})\left[\times 10^{6}\right]$ & Slope $(\mathrm{SE})$ & $\chi^{2 \mathrm{a}}$ & $\mathrm{df}$ & Ratio $(95 \% \mathrm{CL})^{\mathrm{b}}$ \\
\hline \multirow{2}{*}{ MyseNPV G (M) } & M. separata & $0.7(0.2-2.3)$ & $0.81(0.11)$ & $11.81^{*}$ & 4 & - \\
& S. litura & $31.8(21.7-46.5)$ & $1.08(0.09)$ & 1.83 & 3 & $46.1(19.4-109.8)$ \\
MyseNPV G (S) & M. separata & $3.8(2.5-5.9)$ & $0.85(0.07)$ & 5.89 & 4 & - \\
& S. litura & $4.6(2.9-7.3)$ & $1.12(0.12)$ & 5.93 & 4 & $1.2(0.6-2.3)$ \\
\hline
\end{tabular}

\footnotetext{
a Pearson Chi-square for the homogeneity test. Values followed by asterisk are significant $(p<0.05)$.

${ }^{\mathrm{b}}$ Ratio of $\mathrm{LC}_{50} \mathrm{~s}$ with respect to the virus/host combination.
} 


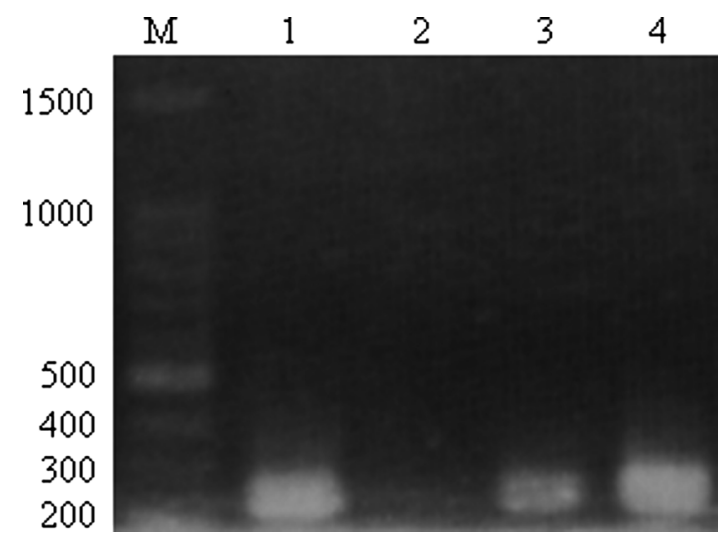

Fig. 3. Examination of MyseNPV samples for the presence of SpltNPV by PCR amplification of a SpltNPV lef- 8 241-bp fragment. Lane 1, MyseNPV G (S) DNA; lane 2, MyseNPV G (M) DNA; lane 3, DNA from occlusion bodies from a mixture of homogenates of 114 individual $S$. litura larvae that died after inoculation with MyseNPV G (M); lane 4, PCR positive control (SpltNPV DNA). Lane M, 100 bp ladder size marker.

separata was more susceptible than S. litura to MyseNPV G (M), the two species were almost equally susceptible to MyseNPV G (S). According to the parallelism test, probit lines for MyseNPV G (M) were not parallel $\left(\chi^{2}=8.53, \mathrm{df}=1, p<0.05\right)$, and this was also the case for MyseNPV G (S) $\left(\chi^{2}=\right.$ 4.27, $\mathrm{df}=1, p<0.05)$. Ratios of $\mathrm{LC}_{50} \mathrm{~s}$ between the two hosts for MyseNPV G (M) and MyseNPV G (S) were 46.1 and 1.2, respectively.

\section{Examination of MyseNPV G}

The purity of each type of MyseNPV G was checked using PCR. SpltNPV was detected in MyseNPV G (S) but not in MyseNPV G (M) (Fig. 3).

\section{Bioassays: examination of progeny virus}

Larvae of $S$. litura and M. separata were inoculated with homogenate prepared from individual cadavers of $S$. litura infected with MyseNPV G (M) in order to verify whether the mortalities were caused by the inoculated MyseNPV G or the latent virus of $S$. litura. Among 115 homogenates made from individual dead larvae of $S$. litura, 114 caused mortality when inoculated into $M$. separata, but one failed to kill M. separata although it provoked death in larvae of $S$. litura. The EcoRI profile of the viral DNA obtained from this unique sample was similar to that of SpltNPV described by Takatsuka et al. (2003) (Fig. 4, lane 4). Sequence analy-

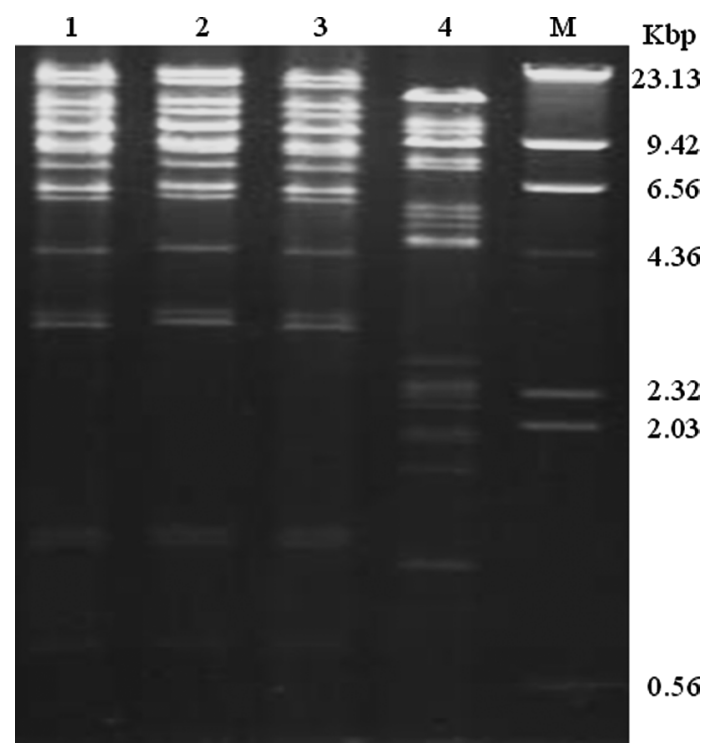

Fig. 4. EcoRI profiles of viral DNA extracted from: lane 1, MyseNPV G; lanes 2 and 3, occlusion bodies from individual $S$. litura that had died after inoculation with MyseNPV G and that caused death in M. separata; lane 4, occlusion bodies from individual $S$. litura that had died after inoculation of MyseNPV $G$ and that failed to kill M. separata. Lane M, $\lambda$-HindIII digest.

sis of the partial lef- 8 gene of DNA from the unique sample (GenBank Accession No. AB451187) amplified by degenerate primers showed 100, 98, 97 , and $59.1 \%$ identity with the lef- 8 sequences of SpltNPV-A17-3 (AY706580), SpltNPV-S37 (AY706581), SpltNPV-G2 (AF325155), and MyseNPV G (AB30847), respectively, confirming that the virus isolated from the unique sample is SpltNPV, a species different from MyseNPV G.

However, although two samples randomly chosen from the other 114 presented EcoRI profiles resembling that of the inoculum MyseNPV G (Fig. 4, lanes 2 and 3), a PCR reaction performed with DNA extracted from OBs of a mixture of the 114 samples revealed the presence of SpltNPV (Fig. 3, lane 3).

\section{DISCUSSION}

Spodoptera litura is permissive for several NPVs. To explore the possibility of using this insect as an alternative host to produce OBs of heterologous NPVs, our study has focused on a latent virus harbored by $S$. litura which may affect some properties of virus samples collected after propagation in larvae of the insect, particularly their viru- 
lence, a very important parameter for the success of NPVs as bioinsecticides.

Latency, defined as the ability of a virus to survive in a host or host generations without causing recognizable symptoms, has been demonstrated in several lepidopteran insects (Podgwaite and Mazzone, 1986; Il'inykh and Ul'yanova, 2005). Thanks to the use of molecular techniques applied mainly to the polyhedrin gene (polh) (Cameron and Possee, 1989; Hughes et al., 1997), evidence for the presence of latent NPV infections of insects has been achieved. The combination of polh and lef- 8 and -9 , two other highly conserved baculoviruses genes, is a very suitable gene set to identify lepidopteran-specific NPVs (de Moreas and Maruniak, 1997; Herniou et al., 2003; Lange et al., 2004; Jehle et al., 2006). The present study could also provide information on a latent virus in S. litura by amplifying target SpltNPV DNA sequences. Based on detection of viral DNA by nested PCR amplification and sequencing of a lef- 8 fragment, we showed that $20 \%$ of eggs and larvae of a healthy laboratory stock of $S$. litura, reared continuously for more than 10 years, proved positive for the virus, indicating that SpltNPV exists in a latent state in S. litura. This result is supported by samples collected from field that showed an infection rate of $22.6 \%$ although no death was recorded in offspring derived from these collections. The virus was detected in samples collected from different geographical locations of Kagoshima Prefecture (Kagoshima City, Ibusuki City and Kanoya City), at different periods. This occurrence of the virus at various places and times permitted us to confirm our results. Our findings are similar to those of Eastwell et al. (1999), who detected latent virus in laboratory cultures, and in $23 \%$ of larvae of codling moth populations from British Columbia, using the PCR reaction. Application of PCR permitted Burden et al. (2003) to demonstrate a higher rate (50 to $100 \%)$ of latent infection in natural cabbage moth populations in England, and, similar to our results, the virus was present in insects from geographically remote regions. Moreover, they demonstrated that the viral infection rate of these insects when reared in the laboratory (under conditions without external viral contamination) usually did not decrease over the five generations during which they were observed. The percentages found in our study might reflect a similarity of infection rates between laboratory stocks and field-collected $S$. litura, as shown for the cabbage moth, although this will need to be monitored over a longer period. Overall, we conclude that this is the first report of a latent NPV infecting S. litura.

The activation of latent virus by heterologous baculoviruses has been discussed over the last 100 years (see Podgwaite and Mazzone, 1986, for a review). For instance, Longworth and Cunningham (1968) demonstrated by morphological and serological analysis that latent virus had been activated in both species when larvae of Aglais urticae and Porthetria (Lymantria) dispar were each fed the NPV of the other species. More recently, Cooper et al. (2003) demonstrated, by analyzing DNA profiles of viruses resulting from cross-inoculation of the forest tent caterpillar Malacosoma disstria with the western tent caterpillar M. californium pluviale NPV (McplNPV), that $88 \%$ of these infections were caused by $M$. disstria NPV (MadiNPV) rather than McpINPV. Our study indicated that a similar phenomenon can occur as a result of propagation of MyseNPV through $S$. litura. Although no SpltNPV genes were detected in the MyseNPV G inoculum, the presence of SpltNPV genes in the OBs of the virus sample obtained after passage through $S$. litura larvae suggested that activation of SpltNPV by MyseNPV G had occurred in S. litura. Our hypothesis was confirmed by sequence analysis and by the EcoRI profile similarity between SpltNPV isolates and that of OBs collected from a $S$. litura larva that died after inoculation with MyseNPV G.

Moreover, the virulence of the heterologous virus MyseNPV G propagated through S. litura (MyseNPV G (S)) was different from that of the same virus propagated through the homologous host M. separata (MyseNPV G (M)). The virus became more infectious to $S$. litura and less infectious to $M$. separata when propagation occurred through this insect, as indicated by the ratios of $\mathrm{LC}_{50} \mathrm{~s}$ between the two hosts for MyseNPV G (M) and MyseNPV G (S), which were 46.1 and 1.2, respectively. The non-pathogenicity to $M$. separata of the unique sample obtained after inoculation of $S$. litura with MyseNPV G suggested that activation of a latent virus was responsible for the change in virulence of the MyseNPV G sample following propagation through $S$. litura. This phenomenon might be the origin of the variability in $\mathrm{LC}_{50} \mathrm{~S}$ in 
the results of Tsuda et al. (2005), Okada (1977), and ours (unpublished data). The $\mathrm{LC}_{50} \mathrm{~s}$ of MyseNPV G recorded by Tsuda et al. (2005) and Okada (1977), who propagated MyseNPV G through $S$. litura, were about $10^{4} \mathrm{OBs} / \mathrm{ml}$, while the $\mathrm{LC}_{50}$ of MyseNPV G propagated through M. separata was about $10^{7} \mathrm{OBs} / \mathrm{ml}$ against second-instar $S$. litura (unpublished data). This variability is not surprising, since SpltNPV has been shown to be $\sim 1,000$-fold more pathogenic than MyseNPV G against $S$. litura (unpublished data).

The use of $S$. litura as an alternative host to produce heterologous NPVs should therefore be reconsidered; at least, it is important to confirm (preferably by nested PCR) the virus-free nature of any $S$. litura, above all in eggs, that are to be used for heterologous NPV production.

\section{ACKNOWLEDGEMENTS}

We express our thanks to Mr. H. Kamiwada and Mr. S. Hayashikawa (Kagoshima Prefectural Institute for Agricultural Development, Kagoshima), and Mr. Y. Dun (Kagoshima University) for their help in insects collection. We appreciate the kindness of Dr. I. Smith (Nara Institute of Science and Technology, Nara) in critical reading of the manuscript. Our thanks are also due to Dr. H. Uematsu (University of Miyazaki), Drs. S. Taoura and K. Sone (Kagoshima University) for technical assistance and advices.

\section{REFERENCES}

Burden, J. P., C. P. Nixon, A. E. Hodgkinson, R. D. Rossee, S. M. Sait, L. A. King and R. S. Hails (2003) Covert infection as a mechanism for long-term persistence of baculoviruses. Ecol. Lett. 2: 524-531.

Cameron, I. R. and R. D. Possee (1989) Conservation of polyhedrin gene promoter function between Autographa californica and Mamestra brassicae nuclear polyhedrosis viruses. Virus Res. 12: 183-199.

Cooper, D., J. S. Cory and D. A. Theilmann (2003) Nucleopolyhedroviruses of forest western tent caterpillars: crossinfectivity and evidence for activation of a latent virus in high-density field populations. Ecol. Entomol. 28: 41-50.

Cory, J. S., J. Z. Hirst, P. H. Sterling and M. R. Speight (2000) Narrow host range nucleopolyhedrovirus for control of the browntail moth (Lepidoptera: Lymantriidae). Biol. Control 29: 661-667.

de Moreas, R. R. and J. E. Maruniak (1997) Detection and identification of multiple baculoviruses using the polymerase chain reaction (PCR) and restriction endonuclease analysis. J. Virol. Methods 63: 209-217.

Eastwell, K. C., J. E. Cossentine and M. G. Bernardy (1999) Characterization of Cydia pomella granulovirus from codling moths in a laboratory colony and in orchards of British Columbia. Ann. Appl. Biol. 134: 285-291.
El-Salamouny, S., M. Lange, M. Jutzi, J. Hubar and J. A. Jehle (2003) Comparative study on the susceptibility of cutworms (Lepidoptera: Noctuidae) to Agrotis segetum nucleopolyhedrovirus and Agrotis ipsilon nucleopolyhedrovirus. J. Invertebr. Pathol. 84: 75-82.

Finney, D. J. (1978) Statistical Methods in Biological Assay. Charles Griffin and Co., London. 588 pp.

Fuxa, J. R., J. Z. Sun, E. H. Weidner and L. R. LaMotte (1999) Stressors and rearing diseases of Trichoplusia ni: evidence of vertical transmission of NPV and CPV. J. Invertebr. Pathol. 74: 149-155.

Hale, W. G. and J. P. Margham (1988) Collins Reference Dictionary: Biology. Collins, Glasgow. 565 pp.

Herniou, E. A., J. A. Olszewski, J. S. Cory and D. R. O'Reilly (2003) The genome sequence and evolution of baculoviruses. Annu. Rev. Entomol. 48: 211-234.

Hughes, D. S., R. D. Possee and L. A. King (1997) Evidence for the presence of a low-level, persistent baculovirus infection of Mamestra brassicae insects. J. Gen. Virol. 78: 1801-1805.

Hunter-Fujita, F. R., P. F. Entwistle, H. F. Evans and N. E. Crook (1998) Insect Viruses and Pest Management. John Wiley \& Sons, Chichester, pp. 407-412.

Il'inykh, A. V. and E. G. Ul'yanova (2005) Latency of baculoviruses. Biol. Bull. 32: 496-502.

Jakubowska, A., M. M. van Oers, J. S. Cory, J. Ziemnicka and J. M. Vlak (2005) European Leucoma salicis NPV is closely related to North American Orgyia pseudotsugata MNPV. J. Invertebr. Pathol. 88: 100-107.

Jehle, J. A., M. Lange, H. Wang, Z. Hu, Y. Wang and R. Hauschild (2006) Molecular identification and phylogenetic analysis of baculoviruses from Lepidoptera. Virology 346: 180-193.

Jurkovíčová, M. (1979) Activation of latent virus infections in larvae of Adoxophyes orana (Lepidoptera: Tortricidae) and Barathra brassicae (Lepidoptera: Noctuidae) by foreign polyhedra. J. Invertebr. Pathol. 34: 213-223.

Lange, M., H. Wang, H. Zhihong and J. A. Jehle (2004) Towards a molecular identification and classification system of lepidopteran-specific baculoviruses. Virology 325: $36-47$.

Longworth, J. F. and J. C. Cunningham (1968) The activation of occult nuclear polyhedrosis viruses by foreign nuclear polyhedra. J. Invertebr. Pathol. 10: 361-367.

Maleki-Milani, H. (1978) Influence de passage répétés du virus de la polyèdrose nucléaire de Autographa califorinica chez Spodoptera littoralis (Lep: Noctuidae). Entomophaga 23: 217-224.

McKinley, D. J., D. A. Brown, C. C. Payne and K. A. Harrap (1981) Cross-infectivity and activation studies with four baculoviruses. Entomophaga 26: 79-90.

Okada, M. (1977) Studies on the utilization and mass production of Spodoptera litura nuclear polyhedrosis virus for control of the tobacco cutworm (Spodoptera litura Fabricius). Bull. Chugoku Nat. Agric. Exp. Sta. Ser. E 12: 1-62 (in Japanese).

Podgwaite, J. D. and H. M. Mazzone (1986) Latency of insect viruses. Adv. Virus Res. 31: 293-320.

Robertson, J. L. and H. K. Preisler (1992) Pesticide Bioas- 
says with Arthropods. CRC Press, Boca Raton. 127 pp. Sakuma, M. (1998) Probit analysis of preference data. Appl. Entomol. Zool. 33: 339-347.

Takatsuka, J., S. Okuno, M. Nakai and Y. Kunimi (2003) Genetic and biological comparisons of ten geographic isolates of a nucleopolyhedrovirus that infects Spodoptera litura (Lepidoptera: Noctuidae). Biol. Control 26: 32-39
Tsuda, K., K. Yamashita, Y. Sakamaki, K. Kusigemati, C. Yasunaga-Aoki, K. Iiyama, M. Okada and T. Kawarabata (2005) Effect of prolonged storage on the virulence of polyhedral inclusion body from seven nucleopolyhedrovirus isolates infectious to the tobacco cutworm, Spodoptera litura (Fabricius) (Lepidoptera: Noctuidae). Jpn. J. Appl. Entomol. Zool. 49: 119-122 (in Japanese with English summary). 